\title{
Environmental Entrepreneurship as an Innovation Catalyst for Social Change: A Systematic Review as a Basis for Future Research
}

\author{
Carol Dineo Diale ${ }^{1, *}$, Mukondeleli Grace Kanakana-Katumba ${ }^{2}$, Rendani Wilson Maladzhi \\ ${ }^{1}$ Department of Psychology, Industrial Psychology, Rhodes University, Grahamstown, 6139, South Africa \\ ${ }^{2}$ Department of Mechanical and Industrial Engineering, University of South Africa, Johannesburg, 0002, South Africa
}

\begin{tabular}{l} 
A R T I C L E I N F O \\
\hline Article history: \\
Received: 09 November, 2020 \\
Accepted: 13 January, 2021 \\
Online: 22 January, 2021 \\
\hline
\end{tabular}

Keywords:

Environmental entrepreneurship

System dynamics

Innovation

\begin{abstract}
A B S T R A C T
There are pressures to adopt sustainable behaviour more so in generating profits and benefiting the society to accelerate green efforts through a green framework. The overarching goal of the paper is premised through various works of literature, building the ecosystem the elements highlighted by most researchers in the field of environmental entrepreneurship. The various models reviewed consists of generic incubators and entrepreneurship, and societal and environmental factors. Environmental entrepreneurship is often used interchangeably with concepts such as green entrepreneurship and ecopreneurship which under-researched globally, with non-existent efforts on the applicability and modelling of key environmental entrepreneurship within a specific context utilising the system dynamics approach. In order to assess the environmental entrepreneurship ecosystem, the authors adopted a system dynamic approach to determine key variables that enable the development of the system. A literature review was conducted, and of the 135 articles reviewed, $n=92$ peer-reviewed articles met the criteria that the researchers set. Some of the results emanating from a systematic review are environmental policy, green skills, financial and non-financial support, societal and behavioural factors, environmental agility, ethics and governance, and access to markets. The theoretical results are simulated using system dynamics modelling. Due to limited research on the abovementioned topic, a possible impacting variable (Exogenous variables) was broadened to add value to, and have an impact on, the study. Upon reviewing the above-mentioned models, the framework emerged signalling elements to be simulated in the system dynamics model, which were then theoretically contextualised for the South African context. The theoretical virtual system dynamic model forming part of the framework will be tested and validated in the next study. The applicability of the theoretical ecosystem to South African context as well as future recommendations are provided in the study.
\end{abstract}

\section{Introduction}

This paper is an extension of "Green Entrepreneurship Model Utilising the System Dynamics Approach: A Review" presented at the IEEM 2019 Conference in Macau [1]. The conference proceeding argued that Green entrepreneurship as a technology is an area that has not been explored fully, let alone its application the system dynamics spectrum. Furthermore, the paper argued that empirical scholarly research in entrepreneurship within Green

*Corresponding Author: Dineo Diale, c.diale@ru.ac.za

www.astesj.com

https://dx.doi.org/10.25046/aj060145 industries is at infancy stages in South Africa, and little research work has been done. In [2], the author conducted a study focusing on green entrepreneurs in the South African context. While [3-5] concentrated on the international markets. However, a complete ecosystem surrounding environmental entrepreneurship, and system dynamics remains a gap under consideration. The existing research is centred around a single factor of green entrepreneurship [1], [3-5], with less focus on finding possible multiple solutions to minimise climatic challenges. In this paper, the focus is on environmental entrepreneurship, particularly with the aim of contributing to social norms and finding innovative 
approaches to utilising system dynamics for modelling endogenous and exogenous variables of the system. In the current paper, the focus of environmental entrepreneurship is within the spectrum of key drivers of environmental entrepreneurship, social change and behavioural factors. The latter focus is deliberate in creating access to services for the community through empowerment, development, and awareness, and ultimately laying a theoretical foundation on how environmental entrepreneurship can be utilised. These efforts may accelerate the sustainable development goals as environmental entrepreneurs are always expected by societies to be concerned with the environmental factors [6]. Some of the literature defined environmental entrepreneurship by using phrases such as ecoentrepreneurship, ecopreneurship, and ecological entrepreneurship [7-9].

Green entrepreneurship and ecopreneurship is minimally included in the current paper. This is due to the fact that the authors are advocating for the concept of green entrepreneurship, ecopreneurship and environmental entrepreneurship to be defined and dealt with separately so as to have an impact and foster the implementation thereof. It is notable that the latter terms are somewhat similar. However, there is a slight difference between the concepts, whereby, Green entrepreneurship focuses on exploiting markets for profits and saving the planet by leveraging green thematic areas [5]; ecopreneurship has a distinctive feature of ensuring efficiency and effectiveness [10]; and environmental entrepreneurship has a distinctive feature of social, behavioural norms to develop and create awareness [11,12]. Environmental entrepreneurship can be defined as the concept of radiating adoption of sustainable behaviour and social entrepreneurship, whilst benefiting the society [11].

The current paper focuses on environmental entrepreneurship by contributing of utilising the system dynamics approach to understand the behaviour of the system and its interaction with sub-systems. A further contribution that the current paper hopes to add is to create a theoretical opportunity of the contribution of environmental entrepreneurship to accelerate the sustainable development goals. The current study illustrates how environmental entrepreneurship contributes to sustainable development, social and behavioural factors affecting environmental entrepreneurship in facilitating access to the service, and fostering environmental entrepreneurship as a form of social change. Social dynamics and sustainable development need to be borne in mind when fully implementing green initiatives to support environmental entrepreneurship. Environmental entrepreneurship, as a complex phenomenon, needs to be viewed from different angles to ensure that solutions are gained from multiple sources at the same time. The underlying goal of the paper is premised through various works such as generic business incubators, environmental factors, and societal norms capitalising on social entrepreneurship to build the ecosystem. From the various models the authors discovered key drivers to environmental entrepreneurship, social and behavioural factors as part of the framework. The theoretical ecosystem consists of key drivers, social and behavioural factors, as well as the theoretical framework contextualised in the South African context. The subsequent sections discuss the research questions methodology, and future recommendations.

\section{Research questions}

The research questions were identified through the research gaps [13] that were identified while reviewing literature and where possible research contributions can be made setting future research agendas. The research questions are as follows:

What are the theoretical key drivers enabling environmental entrepreneurship as a form of social change?

What are theoretical social and behavioural factors affecting environmental entrepreneurship in facilitating access to the service?

How can theoretical key drivers be applied in formulating a South African context framework?

\section{Research Background}

\subsection{Environmental entrepreneurship for social change}

Environmental entrepreneurs need to have an agenda of creating and formulating sustainable and green products and services, and at the same time, meet social, economic and environmental objectives [8], [14-16]. It is essential to focus on social dynamics and sustainable development by fully implementing green initiatives. Goal 5, 'gender equality', of the sustainable development goals can be fulfilled by promoting women in environmental entrepreneurship, and Goal 8, 'inclusive and sustainable economic growth, full and productive employment and decent work for all' [17], can be fulfilled by contributing to a better quality of life and serving as a social change catalyst. Studies have shown that women are more likely to venture into environmental entrepreneurship and are more inclined to uplift communities through social entrepreneurship $[11,18]$.

Research or publication on environmental entrepreneurship as a contribution to sustainable development goals and its interrelatedness or linkages to the system dynamics in the South African context is minimal. Environmental challenges are due to humans not adopting sustainable efforts [19]. The current authors assert that efforts need to be in the form of environmental psychology to minimise challenges due to human activity. Environmental entrepreneurship focuses heavily on the social sphere, transforming communities and the need to adopt agility for the viability of environmental entrepreneurship. In most instances, environmental entrepreneurship forms the foundation of green entrepreneurship by advocating new or innovative ways to save the planet with green products and services [20].

Worldwide, there is minimal research on women as environmental entrepreneurs. In [21], the author holds a strong view that developing women in green cooperatives, especially in rural areas, may alleviate poverty and promote sustainable rural development. This may ultimately contribute to creating green jobs [22]. There has been some effort in tracking environmental entrepreneurship from the early 1990s [23]. Another social factor that has not received much attention is popularising female entrepreneurs who embark on environmental entrepreneurship. There is lack of research on the female identity in relation to their roles as environmental entrepreneurs, which will need to be taken 
into perspective and how they optimise or create a new identity in transitioning into a green economy. In [17], the authors shed some light in proving the motive of women embarking in environmental entrepreneurship is to uplift the society.

The current authors are of the opinion that environmental entrepreneurship can assist in accelerating the sustainable development goals, particularly goal 1: zero poverty, goal 5: gender equality, and goal 8: inclusive and sustainable economic growth, full and productive employment and decent work for all.

\subsection{The innovative contribution of environmental entrepreneurship utilising system dynamics modelling}

The innovative contribution of environmental entrepreneurship as a social change is in the form of system dynamics modelling. The system dynamics approach models the key drivers and factors affecting environmental entrepreneurship as well as social and behavioural factors that create a new perspective of a theoretical entrepreneurship framework. Environmental entrepreneurship, as a complex phenomenon, needs to be viewed from different angles to ensure that solutions are obtained from multiple sources at the same time. System dynamics is used to conceptualise the causal loop relationships or stocks and flows, with the intention of identifying variables that affect the ecosystem feeding into the whole system [24-26]. "System dynamics is the combination of theory, method and philosophy in analysing the behaviour of the system [26]." Furthermore, system dynamics focuses on a feedback loop and nonlinear relationships [25]. System dynamics is viewed as the process or feedback relationship between different parts to understand complexity and behaviour throughout the lifespan, or the process of the system [27]. The need to utilise the complex system to have holistic thinking serves as a research agenda [28]. Therefore, the authors of the current paper further contribute to the system dynamics approach or modelling by looking at environmental entrepreneurship as a complex factor.

\section{Methodology}

The research methodology followed was in the form of systematic review. The rationale for using a systematic review as a methodology afforded the authors access to the various methodologies and outcomes within the areas of environmental entrepreneurship and various societal norms. This enabled the researchers to formulate a framework with triangulation of efforts from previous researchers. Furthermore, the rationale for systematic review is to explore the area under investigation, simulate theoretically, the key drivers, social and behavioural support factors in quest to create a future research agenda free of bias. The systematic review as a methodology was beneficial, especially during the COVID-19 pandemic, which has affected the entire world, as interviews or questionnaires would not have succeeded during these challenging times. The use of online data collection still poses challenges due to social inequalities and the majority of people not having access to emails or not being able to afford online video platforms in South Africa. The systematic review focused on peer-reviewed articles utilising search engines such as Google Scholar, Sage (Journal of Entrepreneurship Theory and Practice), the Journal of Cleaner Production, Science Direct and the Journal of Sustainability. Grey resources such as newspapers media alerts were excluded when conducting a systematic review. A theoretical review was conducted using a literature review of which $n=92$ sources (peer-reviewed articles) out of 135 articles, met the criteria that the researchers set for the ecosystem. Duplication of results was removed from the 135 articles. The current study is qualitative in nature and thematic content analysis was used to analyse the results. According to [29], the most preferred and effective way to analyse a qualitative study is to use thematic content analysis. Content thematic analysis attempts to summarise comments into meaningful categories [29]. According to [30] content analysis is a general term to analyse text. It is the systematic coding pillar used for exploring a large amount of textual information to determine trends and patterns [30]. Furthermore, content thematic analysis enables the researcher to condense a broad and clear description of a factor. Themes that have emerged from a review of the literature are environmental entrepreneurship (in terms of key drivers and support), and social and behavioural factors regarding environmental entrepreneurship. The search criteria were environmental entrepreneurship, and system dynamic social factors regarding environmental entrepreneurship, with a refined search from 2010-2020. The software, Vensim, was utilised to simulate the virtual abstract system dynamics model. The title, introduction, abstract and findings sections were used to select the relevant articles and discard other articles. The findings are summarised in Table 1.

\section{Findings}

The identification of environmental key drivers was affected by conducting an entrepreneurship ecosystem. In order for sustainable entrepreneurship to flourish, awareness of environmental challenges and how they currently affect the nation needs to be set as a research agenda. The literature review and themes such as environmental entrepreneurship (in terms of key drivers and support), and social and behavioural factors regarding environmental entrepreneurship, served as a form of reference. The latter enabled the researchers to manipulate the key variables or drivers for environmental entrepreneurship to be popularised. Environmental entrepreneurship needs to be analysed using small and large-scale criteria and weighed up against the weakness and strengths in order for individuals to learn from and serve, as best practices.

The themes and summary of the afore-mentioned findings are explained in the Table 1. The ecosystem of environmental entrepreneurship in this paper comprises of key drivers in a form of financial and non-financial support, social and behavioural factors as depicted in table 1 .

The key drivers such as funding, credit, capital financing, investing in environmental entrepreneurship, and crowdfunding, can be classified under green finance mechanisms in support of environmental entrepreneurship with social orientation $[9,29]$, [30-33], [35, 36], [44, 45]. Funding of enterprises or ventures is always a challenge, more specifically financing environmental entrepreneurship. Green proofing as advocated by [43] gives rise to a consultancy option, which the current authors deduce that the programme can be utilised to facilitate and manage green change dynamics. Some of the pillars supporting environmental entrepreneurship are infrastructure, skills and education, funding, 
(environmental entrepreneurship incubators) products, markets affordability and political will [12, 29, 30, 33, 43]. However, the latter financial key drivers cannot operate in isolation and therefore, may need non-financial support in the form of behavioural change. With key drivers illustrated above, the next theme leads us to behavioural and social factors to strengthen the ecosystem of environmental entrepreneurship

Table 1: Ecosystem for environmental entrepreneurship

\begin{tabular}{|l|l|l|l|}
\hline $\begin{array}{l}\text { Key drivers of } \\
\text { environmental } \\
\text { entrepreneurship }\end{array}$ & $\begin{array}{l}\text { Social and } \\
\text { behavioural } \\
\text { factors }\end{array}$ & $\begin{array}{l}\text { Authors' } \\
\text { contribution to } \\
\text { the } \\
\text { environmental } \\
\text { entrepreneursh } \\
\text { ip (South } \\
\text { African } \\
\text { context) }\end{array}$ & $\begin{array}{l}\text { Common } \\
\text { factors } \\
\text { from } \\
\text { various } \\
\text { models }\end{array}$ \\
\hline $\begin{array}{l}\text { Strategic support } \\
\text { mechanism [29] }\end{array}$ & $\begin{array}{l}\text { Modelling of } \\
\text { human behaviour }\end{array}$ & $\begin{array}{l}\text { Ambassadors or } \\
\text { society } \\
\text { representatives } \\
\text { from various } \\
\text { cultural groups, } \\
\text { tribal kings, } \\
\text { ward } \\
\text { councillors and } \\
\text { volunteers }\end{array}$ & $\begin{array}{l}\text { Strategic } \\
\text { alliance }\end{array}$ \\
\hline $\begin{array}{l}\text { Environmental } \\
\text { policy [12,30] }\end{array}$ & $\begin{array}{l}\text { Societal support, } \\
\text { Alertness, } \\
\text { motivation, } \\
\text { Altruism [32] }\end{array}$ & $\begin{array}{l}\text { Curriculum } \\
\text { review and } \\
\text { service-learning }\end{array}$ & $\begin{array}{l}\text { Collaboration, } \\
\text { wellbeing, } \\
\text { alliance and } \\
\text { governance }\end{array}$ \\
\hline $\begin{array}{l}\text { Tax exemptions and } \\
\text { tax breaks, financial } \\
\text { mechanism, cost } \\
\text { effective products } \\
\text { and services [31,32] }\end{array}$ & $\begin{array}{l}\text { Crowdfunding, } \\
\text { impact of social } \\
\text { norms, } \\
\text { development } \\
\text { agencies [35-38] }\end{array}$ & $\begin{array}{l}\text { Memorandum } \\
\text { of } \\
\text { understanding, } \\
\text { exchange } \\
\text { programmes, } \\
\text { and } \\
\text { international } \\
\text { linkages }\end{array}$ & $\begin{array}{l}\text { Financial and } \\
\text { Non-financial } \\
\text { support }\end{array}$ \\
\hline $\begin{array}{l}\text { Access to markets, } \\
\text { legal support [12; } \\
30,33,34]\end{array}$ & $\begin{array}{l}\text { Environmental } \\
\text { psychology } \\
\text { Environmental } \\
\text { consciousness, } \\
\text { collective } \\
\text { Environmental } \\
\text { entrepreneurship } \\
\text { and green } \\
\text { behaviour, } \\
\text { Pro environmental } \\
\text { behaviour [39-44] }\end{array}$ & $\begin{array}{l}\text { programme } \\
\text { areen change }\end{array}$ & $\begin{array}{l}\text { Green } \\
\text { consumer } \\
\text { behaviour } \\
\text { and } \\
\text { adoption } \\
\text { of green } \\
\text { behaviour }\end{array}$ \\
\hline
\end{tabular}

The behavioural and social factors are premised within environmental agility innovation, transformation, motivation, ecopreneurial management, profiling of environmental entrepreneurship, development agencies crowdfunding, environmental policy, legal framework business incubators commitment and green skills to govern the rights of environmental entrepreneurs [28-30], [34-38], [45-54]. More entrepreneurs from small scale enterprises are environmentally conscious [55]. Literature suggests that in order for desired change to take place, social context plays a huge role, drawing from the work of $[56,57]$. Society can play a huge role in praising and supporting environmental innovation, whereas entrepreneurs could ensure that they exploit the markets and ensure they offer affordable products and services to the communities at large. The support from government is needed to contribute to the subsidies and waiving of some costs relating to environmental entrepreneurship, as part of the key drivers [57,58]. Networks, non-governmental stakeholders, financial structural support systems, tax exemptions and tax breaks are some of the key drivers that can support environmental entrepreneurship [29, 59]. The authors are proposing that skills development and human capital need to be the cornerstone of accelerating environmental entrepreneurship through an environmental entrepreneurship talent pipeline. The motives of environmental entrepreneurship have been shown that education is a factor. It has been proved that if individuals have higher levels of education, they tend to embark on environmental entrepreneurship [11].

The system dynamics approach is in the form of modelling the key drivers and factors affecting environmental entrepreneurship as explained above, as well as social and behavioural factors creating a new perspective of entrepreneurship. The modelling of the afore-mentioned results can be depicted using the system dynamics model in Figure 1.

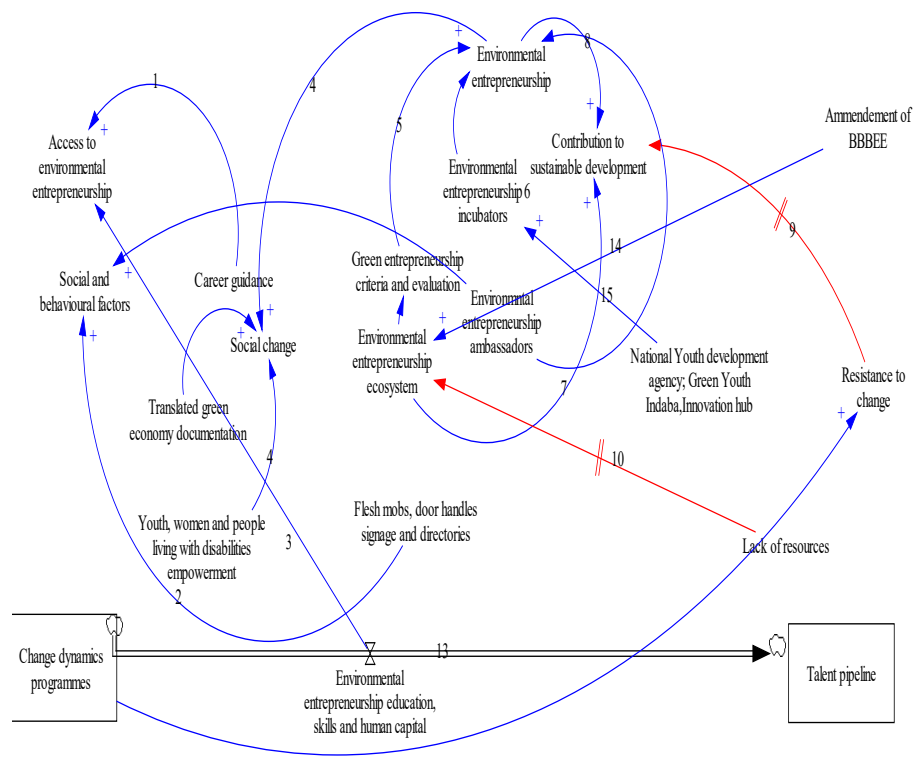

Figure 1: Virtual system dynamics model of environmental entrepreneurship

The system dynamics model (Figure 1) illustrates the importance of the interdependency of multiple variables or factors within the environmental entrepreneurship spectrum. The $(+)$ sign represents a positive relationship and the (-) sign represents a negative relationship. Numbers depict each loop, while delays and threats are represented by a red line with two strokes. The system dynamics model consists of stocks and flows. Loop number 1 represents accessibility services that are influenced by career guidance, and the stock is represented by environmental entrepreneurship education, skills and human capital (loops 3 and 13).

Loop 2 represents an order for social and behavioural factors to be understood and incorporated for social change; and societies can be reached through flesh mobs, door handle signage, directories and ambassadors. Empowering youth, women and people living with disabilities about how to enter the environmental markets, contribute to a social change. Social change then may accelerate environmental entrepreneurship. For 
environmental entrepreneurship to gain momentum, the criteria and evaluation system needs to be in place (loop 5).

Furthermore, contribution to environmental entrepreneurship can gain momentum because of the ambassadors, environmental entrepreneurship incubators (loop 6) and centres such as the National Youth Development Agency, Green Youth Indaba, Innovation Hub (loop 15) and emerging environmental entrepreneurship non-profit and profit organisations. Additionally, business incubators are influenced by financial and non-financial mechanisms as exogenous variables.

Environmental entrepreneurship serves as catalyst and contribution to sustainable development positively demarcated by loop 8 and loop 7. However, resistance to change and a lack of resources causes delays and threats to the ecosystem represented by loops 9 and 10. At the same time, there are inputs from the environment, which is BBBEE or legislation represented by a loop 14, which contribute positively to the environmental entrepreneurship ecosystem.

Stocks and flows are indicated by number loop 13 . Currently, this research proposes two stocks namely change dynamics and talent pipeline, which are influenced and accelerated by environmental entrepreneurship, education and skills. At the same time, environmental change dynamics can be used to minimise resistance to change.

\section{Discussions of environmental entrepreneurship key drivers and social factors}

\subsection{Key drivers of environmental entrepreneurship}

Previous research suggests that creating a clientele, market, and support for the business are important pillars for a start-up to flourish [26]. One important factor that will determine the success or failure of a business is customers and customers' attitudes, which is often overlooked. Creation of the market and funding, or any support for green entrepreneurship, appears to be taboo and an unheard-of practice, therefore, it can be deduced that it needs to start with creating awareness, and unpacking human behaviour as an action. The process needs to be simplified for communities to understand the green economy phenomenon and from there, gradually improve to investigating if there is capability to optimise resources and opportunities for business gain and profit generation and saving the planet for future generations.

There is lack of investors which poses challenges and threats to the system. Investors in environmental entrepreneurship, especially in these sectors, are cautious investors, where scepticism and reluctance arise when it comes to investing to environmental entrepreneurship enterprises. In [33], the author serves to close the gap of financing by introducing crowdfunding. Crowdfunding can be explained as the sourcing of funds through other mechanisms within the lenses of cultural and social norms and creating initiatives online to raise funds and finance. The initiatives to enable transition and a green economy are to ensure ambassadors or champions in different sectors are available. These sectors include the private, public, tertiary, and schooling sectors, and are to be included from the planning phase to the implementation phase. However, society at large or communities are bypassed, and this may add to further challenges and delays in the adoption of new behaviour such as the environmental entrepreneurship. In order to capitalise on collective efficacy in transitioning to a green economy, society, and stakeholders, need to form part of the movement. Collective efficacy can be defined as a group of people coming together to remedy a challenge (as in this instance, the environmental challenges), and have the confidence and capabilities to embark on the movement [41].

The need for curriculum review and inclusion of environmental entrepreneurship in South African basic and higher education needs to be considered to ensure the sustainability of environmental entrepreneurship. In [43], the author echoes the latter idea of curriculum inclusion of environmental entrepreneurship in schools. The green skills documentation and lessons learnt could be drawn from parts of Europe in regulating the economic factor of green skills for the country's economy [59]. The SEED programme is another support mechanism that supports sustainability entrepreneurship [60-62].

\subsection{Societal and behavioural factors}

There is an action of social responsibilities and environmental policies to be modified concurrently of which the researchers believe that environmental entrepreneurship with the lens of system dynamics could be incorporated onto policies to view the challenge as a system. A study conducted in Bosnia asserts that there is role ambiguity among government stakeholders and educational curricula regarding green entrepreneurship [63]. The latter argument can then be strengthened, and a clear framework provided where relevant stakeholders have stipulated the role and support required to accelerate the agency of adoption of environmental entrepreneurship.

\subsection{Threats to the environmental entrepreneurship system}

Through the analysis of literature, there have been efforts to investigate green entrepreneurship from international perspectives. Researchers then grouped existing literature to identify barriers to environmental entrepreneurship. Some of the internal barriers were a lack of resources and adequate knowledge, poor implementation of policies and strategies, and attitudes and an organisational culture that discourage environmental management [34]. Furthermore, external barriers that were identified were, difficulty in obtaining certification for environmental practices and systems, economic uncertainty, a lack of legal and institutional frameworks, specialised support and networks among small businesses and the creation of green jobs, and non-compliance with policies. The lens in regard to level of education, support services for incubation, entrepreneurial confidence, business climate, job creation, and clientele may be the solution to the above-mentioned challenges.

\subsection{Contextualisation to the South African context}

The authors believe that South Africa can implement strong coordination in the form of a memorandum of understanding with the countries that have developed environmental entrepreneurship. This will allow exchange programmes within the SMEs in diverse environmental entrepreneurship, particularly targeting Youth, Black people, women and people living with disabilities. 
To broaden this perspective, Broad-based Black Economic Empowerment (BBBEE) needs to also include additional lenses of facilitating environmental entrepreneurship, and points should be allocated in the form of tendering systems in diverse environmental entrepreneurship. To promote gender equality, goal 5 of the sustainable development goals, environmental entrepreneurship can be spearheaded through women empowerment and be integrated into the BBBEE codes to ensure the economic and social standing of women in the South African context. Furthermore, to facilitate the access of services, the scope of career guidance can be expanded to include environmental entrepreneurship as a transformative process. The authors offer recommendations to accelerate access to markets and provide social contexts that are to be embedded in environmental entrepreneurship. In order to further accelerate access to markets, environmental policy needs to specifically stipulate what the rights of environmental entrepreneurs are and how they can access markets $[12,42]$.

The environmental entrepreneurship pipeline needs to be in place and included in policies, that especially target the youth. The National Youth Development Agency could spearhead funding and include the criteria to promote entrepreneurship in environmentally friendly products, services, consulting or distribution. The National Youth Development Agency could work hand in hand with Green Youth Indaba and an Innovation Hub where several youth programmes are housed, to ensure the sustainability of entrepreneurship in targeting the youth. Environmental change dynamics should be implemented whereby green readiness of change and managing fear of the unknown within Green initiatives could be developed, and awareness and training initiatives with environmental enterprises are instilled into society to contribute to the level of confidence in sustainable energy enterprise sectors. Green skills can be incorporated into the South African Skills Development Act to facilitate an initiative regarding green skills training and development. Change dynamics programmes such as resistance to change and sustainable development goals in a developing country can be introduced. The existing change dynamics programmes can be used as a foundation to design and implement the ecosystem. The South African Skills Development Act could be amended to facilitate the initiative of training and development, and the keeping of training and development records to aid sustainable development goals, and green skills for monitoring of grants and incentives.

\section{Future recommendation}

Action is needed with regards to social responsibilities. Further action is for environmental policies to incorporate environmental entrepreneurship. The authors further contribute that in order for environmental challenges to be minimised and environmental entrepreneurship to flourish, human behaviour needs to be modelled through environmental Psychology in terms of social psychology, behaviour, motivation, cultural and gender factors, personality traits, and attitudes towards a green economy and environmental entrepreneurship. To further aid environmental entrepreneurship as a social change, the development and focus of research and support needs to be given to women.

\section{Conclusions}

The current paper explored various works of literature such as key drivers from business incubators, social and behavioural factors, environmental entrepreneurship, and building the theoretical ecosystem of the elements highlighted by most researchers in the field of environmental entrepreneurship. Environmental entrepreneurship, as a complex phenomenon, needs to be viewed from different angles to ensure that solutions are gained from multiple sources at the same time.

The discovery made during the review of literature is that an ecosystem of environmental entrepreneurship can be broadly clustered within key drivers (support and accelerators), and social and behavioural factors that are contextualised in the South African context. The latter broad factors can further be explained through the accessibility of services that are influenced by career guidance, environmental entrepreneurship education skills and human capital. In order for social and behavioural factors to be understood and incorporated for social change, societies can be reached through flesh mobs, door handle signage, directories and ambassadors.

The empowerment of youth, women and people living with disabilities about how to enter the sphere of environmental entrepreneurship needs to be the cornerstone and serve as an accelerator to the system. Therefore, environmental entrepreneurship serves as catalyst and contributes to sustainable development, theoretically. As a way forward, the above hypothesis needs to be tested and validated to build a systems dynamic model taking foundation from the systematic review conducted by the current authors. Furthermore, to try and bridge the gap, more interdisciplinary qualifications need to be encouraged and a call for industrial psychologists to collaborate with experts in the fields of industrial engineering, environmental science and economics, about meeting sustainable development goals, should be undertaken.

\section{Conflict of Interest}

The authors declare no conflict of interest

\section{Acknowledgment}

The authors would like to thank the anonymous reviewers of the IEEE IEEM conference proceedings, which ultimately led to the extension of conference proceedings and thereby, the journal publication. The authors would also like to thank the reviewers and organisers of the first annual French-South Africa innovation days held in December 2019, which also contributed to the publication of the current paper.

\section{References}

[1] C.D. Diale, G. Kanakana-Katumba \& R.W. Maladzhi. Green Entrepreneurship Model Utilising the System Dynamics Approach: A Review. In 2019 IEEE International Conference on Industrial Engineering and Engineering Management (IEEM) 384-389. (IEEE), 2019, December. doi.org/10.1109/IEEM44572.2019.8978804.

[2] C. Mukonza. Analysis of Factors Influencing Green Entrepreneurship in South Africa, 2016.

[3] F. Farinelli, M. Bottini, S. Akkoyunlu, P. Aerni \& P. Green entrepreneurship: the missing link towards a greener economy. Atdf Journal, 8(3/4), 42-48, 2011 . 
[4] M. Schaper. Understanding the green entrepreneur. In Making Ecopreneurs, 27-40. Routledge, 2016.

[5] P.N. Vaidya \& D.V. Honagannavar. Green entrepreneurship towards sustainable environment. International Journal of commerce and management 3(1), 88-91, 2017.

[6] J.C. Allen \& S. Malin. Green entrepreneurship: a method for managing natural resources? Society and natural resources, 21(9), 828-844, 2008. doi.org/10.1080/08941920701612917.

[7] A. Kuckertz \& M. Wagner. The influence of sustainability orientation on entrepreneurial intentions - Investigating the role of business experience. Journal of Business Venturing, 25(5), 524-539, 2010. doi.org/10.1016/j.jbusvent.2009.09.001.

[8] M. Lenox \& J.G. York. Environmental entrepreneurship. The Oxford handbook of business and natural environment, 70-92, 2011.doi.org/10.1093/oxfordhb/9780199584451.003.0004.

[9] E. Mieszajkina. Ecological entrepreneurship and sustainable development. Problemy Ekorozwoju-Problems of Sustainable Development, 12 (1), 163-171. 2016

[10] L. Walley, D. Taylor \& K. Greig. Beyond the visionary champion: Testing a typology of green entrepreneurs. Making ecopreneurs: developing sustainable entrepreneurship, 2, 59-74, 2010.

[11] J. Hörisch, J. Kollat \& S.A. Brieger. What influences environmental entrepreneurship? A multilevel analysis of the determinants of entrepreneurs' environmental orientation. Small Business Economics, 48(1), 47-69, 2017.

[12] L.E. Huggins. Environmental entrepreneurship: markets meet the environment in unexpected places. Edward Elgar Publishing, 2013.

[13] J.W. Creswell \& J.D. Creswell. Research design: Qualitative, quantitative, and mixed methods approaches. Sage publications, 2017.

[14] J. Kirkwood \& S. Walton. What motivates ecopreneurs to start businesses? International Journal of Entrepreneurial Behavior \& Research, 16(3), 204-228, 2010. doi.org/10.1108/13552551011042799.

[15] T. McEwen. Ecopreneurship as a solution to environmental problems: implications for college level entrepreneurship education. International Journal of Academic Research in Business and Social Sciences, 3(5) 264, 2013.

[16] D. Vasilevska \& B. Rivza. Green Entrepreneurship as a Factor of Sustainable Economic Development in Baltic States. International Multidisciplinary Scientific GeoConference: SGEM, 18(5.3), 423-430, 2018. doi.org/10.5593/sgem2018/5.3/S28.054.

[17] A.R. Nunes, K. Lee \& T. O'Riordan. The importance of an integrating framework for achieving the Sustainable Development Goals: the example of health and well-being. BMJ global health, 1(3) e000068, 2016. doi.org/10.1136/bmjgh-2016-000068.

[18] D.M. Hechavarria, A. Ingram., R. Justo \& S. Terjesen. Are women more likely to pursue social and environmental entrepreneurship? In Global Women's Entrepreneurship Research. Edward Elgar Publishing, 2012. doi.org/10.4337/9781849804752.00016.

[19] G. Nhamo. Green economy readiness in South Africa: A focus on the national sphere of government. International Journal of African Renaissance Studies-Multi-, Inter-and Transdisciplinarity, 8(1), 115-142, 2013. doi.org/10.1080/18186874.2013.834628.

[20] V. Harini. \& D.T. Meenakshi. Green Entrepreneurship Alternative (Business) Solution to Save Environment. Asia Pacific Journal of Management \& Entrepreneurship Research, 1 (3), 79, 2012.

[21] S.E. Sanyang \& W.C. Huang. Green cooperatives: A strategic approach developing women's entrepreneurship in the Asian and Pacific region. World Journal of Agricultural Sciences, 4(6), 674-683, 2008.

[22] M. Drăgoi, I.E. Iamandi, S. Munteanu, R. Ciobanu \& R. Lădaru. Incentives for developing resilient agritourism entrepreneurship in rural communities in Romania in a European context. Sustainability, 9(12), 2205, 2017. doi.org/10.3390/su9122205.

[23] D. Holt. Where are they now? Tracking the longitudinal evolution of environmental businesses from the 1990s. Business Strategy and the Environment, 20(4), 238-250, 2011. doi.org/10.1002/bse.697.

[24] D.H. Meadows. Thinking in systems: A primer. Chelsea green publishing, 2008.

[25] J.W. Forrester. Some basic concepts in system dynamics. Sloan School of Management, Massachusetts Institute of Technology, Cambridge, 9, 2009.

[26] R. Teplov, J. Väätänen \& D. Podmetina. A System Dynamic Approach to Modelling the Endogenous and Exogenous Determinants of the Entrepreneurship Process. Journal of Innovation Management, 4(2), 68-95, 2016. doi.org/10.24840/2183-0606_004.002_0005

[27] N. Abdelkafi \& K. Täuscher. Business models for sustainability from a system dynamics perspective. Organization \& Environment, 29(1), 74-96, 2016. doi.org/10.1177/1086026615592930.
[28] K. Schaefer, P.D. Corner \& K. Kearins. Social, environmental and sustainable entrepreneurship research: what is needed for sustainability-asflourishing? Organization \& environment, 28(4), 394-413, 2015. doi.org/10.1177/1086026615621111.

[29] D. Waddell, A. Creed, T.G. Cummings \& C.G. Worley. Organisational change: Development and transformation. Cengage AU, 2019

[30] M. Vaismoradi, H.Turunen \& T. Bondas. Content analysis and thematic analysis: Implications for conducting a qualitative descriptive study. Nursing \& health sciences, 15(3), 398-405, 2013. doi.org/10.1111/nhs.12048.

[31] P.B. Zamfir. (2014). Supporting Green Entrepreneurship in Romania: Imperative of Sustainable Development. Romanian Econ. Bus. Rev, 9, 3544, 2014.

[32] N. Thompson, K. Kiefer \& J.G. York. Distinctions not dichotomies: Exploring social, sustainable, and environmental entrepreneurship. In Social and sustainable entrepreneurship. Emerald Group Publishing Limited, 2011 doi.org/10.1108/S1074-7540(2011)0000013012.

[33] A.V. Barkov \& Y.S. Grishina. Methodological approaches to theoretical construction of the model of legal support for environmental entrepreneurship. Civil Law 4, 3-7, 2018. doi.org/10.33397/2619-05592019-1-1-115-134.

[34] O.A. Yakovleva. Environmental entrepreneurship (legal aspect). Legal Concept= Pravovaya Paradigma, 17(2), 2018.

[35] J. Hörisch. Crowdfunding for environmental ventures: an empirical analysis of the influence of environmental orientation on the success of crowdfunding initiatives. Journal of cleaner production, 107, 636-645, 2015. doi.org/10.1016/j.jclepro.2015.05.046.

[36] F. Massa-Saluzzo \& L. Toschi. The Impact of Local Social Norms on Access to Finance: The Case of Environmental Entrepreneurship. In Academy of Management Proceedings 2019, (1), 14820. Briarcliff Manor, NY 10510: Academy of Management, 2019, July. doi.org/10.5465/AMBPP.2019.38.

[37] E.I. Nikolaou, D. Ierapetritis \& K.P. Tsagarakis. An evaluation of the prospects of green entrepreneurship development using a SWOT analysis. International Journal of Sustainable Development \& World Ecology, 18(1), 1-16, 2011. doi.org/10.1080/13504509.2011.543565.

[38] C. Rodgers. Sustainable entrepreneurship in SMEs: a case study analysis. Corporate Social Responsibility and Environmental Management, 17(3), 125-132, 2010. doi.org/10.1002/csr.223.

[39] S. Schaltegger \& M. Wagner. Sustainable entrepreneurship and sustainability innovation: categories and interactions. Business strategy and the environment, 20(4), 222-237, 2011. doi.org/10.1002/bse.682.

[40] S. Schaltegger. A framework and typology of ecopreneurship: Leading bioneers and environmental managers to ecopreneurship. In Making Ecopreneurs pp. 95-114. Routledge, 2016.

[41] S. Cheema, B. Afsar, B.M. Al-Ghazali \& A. Maqsoom. How employee's perceived corporate social responsibility affects employee's proenvironmental behaviour? The influence of organizational identification, corporate entrepreneurship, and environmental consciousness. Corporate Social Responsibility and Environmental Management, 27(2), 616-629, 2020. doi.org/10.1002/csr.1826.

[42] J.P. Doh, P. Tashman \& M.H. Benischke. (2019). Adapting to grand environmental challenges through collective entrepreneurship. Academy of management perspectives, 33(4), 450-468, 2019. doi.org/10.5465/amp.2017.0056

[43] I. Fritsche, E. Jonas \& T. Kessler. Collective reactions to threat: Implications for intergroup conflict and for solving societal crises. Social Issues and Policy Review, 5(1), 101-136, 2011. doi.org/10.1111/j.17512409.2011.01027.x.

[44] W.R. Meek, D.F. Pacheco \& J.G. York. The impact of social norms on entrepreneurial action: Evidence from the environmental entrepreneurship context. Journal of Business Venturing, 25(5), 493-509, 2010. doi.org/10.1016/j.jbusvent.2009.09.007.

[45] K. Foster, J. Jelen \& A. Scott. (2010). Teaching Environmental Entrepreneurship at an Urban University: Greenproofing. Metropolitan Universities, 21(1), 73-87, 2010

[46] R. Ranjan. Deriving double dividends through linking payments for ecosystem services to environmental entrepreneurship: The case of the invasive weed Lantana camara. Ecological Economics, 164, 106380, 2019. doi.org/10.1016/j.ecolecon.2019.106380.

[47] R. Antolin-Lopez, J. Martinez-del-Rio \& J. J. Cespedes-Lorente. Environmental entrepreneurship as a multi-component and dynamic construct: Duality of goals, environmental agency, and environmental value creation. Business Ethics: A European Review, 28(4), 407-422, 2019. doi.org/10.1111/beer.12229.

[48] A. Domańska, B. Żukowska \& R. Zajkowski. Green entrepreneurship as a connector among social, environmental and economic pillars of sustainable 
development. Why some countries are more agile? Problemy Ekorozwoju, 13(2), 2018

[49] A. de Bruin \& K. Lewis. Little acorns in action: green entrepreneurship and New Zealand micro-enterprises. Making ecopreneurs: Developing sustainable entrepreneurship, 95-107, 2010.

[50] J. L. Thompson \& J. Scott. Environmental entrepreneurship: The sustainability challenge, 2010.

[51] J.K. Hall, G.A. Daneke \& M.J. Lenox. Sustainable development and entrepreneurship: Past contributions and future directions. Journal of business venturing, 25(5), 439-448, 2010. doi.org/10.1016/j.jbusvent.2010.01.002.

[52] J.M. Scott. \& J. Thompson. Making ecopreneurs: developing sustainable entrepreneurship. International Journal of Entrepreneurial Behavior \& Research, 2012. doi.org/10.1111/joms. 12214.

[53] G.D. Markman, M. Russo, G.T. Lumpkin, P.D. Jennings \& J. Mair. Entrepreneurship as a platform for pursuing multiple goals: A special issue on sustainability, ethics, and entrepreneurship. Journal of Management Studies, 53(5), 673-694, 2016.

[54] J. Thompson. Incredible Edible-social and environmental entrepreneurship in the era of the "Big Society". Social Enterprise Journal, 2012.

[55] M. Schaper. Understanding the green. Making ecopreneurs: Developing sustainable entrepreneurship, 7, 2010

[56] K. Hockerts \& R. Wüstenhagen. Greening Goliaths versus emerging Davids-Theorizing about the role of incumbents and new entrants in sustainable entrepreneurship. Journal of business venturing, 25(5), 481-492, 2010. doi.org/10.1016/j.jbusvent.2009.07.005.

[57] J.A. Schumpeter. "Economic theory and entrepreneurial history", in Clemence, R.V. (Ed.), Essays on Entrepreneurship, Innovations, Business Cycles, and the Evolution of Capitalism, 7th ed., Transaction Publishers, New Brunsick, NJ, 254-72, 2004. doi.org/10.4324/9781351311489-21.

[58] S. Choudhary. \& N. Patil. Green entrepreneurship: role of entrepreneurs in energy economics in Nepal. Annual Research Journal of Symbiosis Centre for Management Studies, 3(1), 166-175, 2015.

[59] M. Loock. Going beyond best technology and lowest price: on renewable energy investors' preference for service-driven business models. Energy Policy 40, 21-27, 2012. doi.org/10.1016/j.enpol.2010.06.059.

[60] Y.D. Uslu, Y. Hancıoğlu \& E. Demir. Applicability to green entrepreneurship in Turkey: A situation analysis. Procedia-Social and Behavioral Sciences, 195, 1238-1245, 2015. doi.org/10.1016/j.sbspro.2015.06.266.

[61] OECD/Cedefop, Greener Skills and Jobs, OECD Green Growth Studies, OECD Publishing. doi.org/10.1787/9789264208704-en, (2014).

[62] H. Creech, L. Paas, G.H. Gabriel, V. Voora, C. Hybsier \& H. Marquard. Small-scale social-environmental enterprises in the green economy: supporting grassroots innovation. Development in Practice, 24(3), 366-378, 2014. doi.org/10.1080/09614524.2014.899561.

[63] I. Silajdžić, S.M. Kurtagić \& B. Vučijak. Green entrepreneurship in transition economies: a case study of Bosnia and Herzegovina. Journal of Cleaner Production, 88, 376-384, 2015. doi.org/10.1016/j.jclepro.2014.07.004. 